\title{
Solid urban waste in the production of Aegiphila sellowiana Cham. seedlings
}

\author{
Marcos V. W. Caldeira ${ }^{1}$, Fernando E. V. Santos ${ }^{2}$, Sustanis H. Kunz ${ }^{1}$, \\ Valéria H. Klippel ${ }^{1}$, William M. Delarmelina ${ }^{3}$ \& Elzimar de O. Gonçalves ${ }^{1}$ \\ ${ }^{1}$ Universidade Federal do Espírito Santo/Centro de Ciências Agrárias e Engenharias/Departamento de Ciências Florestais e da Madeira. Jerônimo Monteiro, \\ ES. E-mail: mvwcaldeira@gmail.com - ORCID: 0000-0003-4691-9891; sustanishk@yahoo.com.br - ORCID: 0000-0001-6937-7787; vhklippel@gmail.com \\ (Corresponding author) - ORCID: 0000-0003-0990-9555; elzimarog@yahoo.com.br - ORCID: 0000-0001-7675-2493 \\ ${ }^{2}$ Escola Municipal “Cônego Bento". Carmésia, MG. E-mail: fernandoelair@gmail.com - ORCID: 0000-0001-6384-0689 \\ ${ }^{3}$ Instituto Federal de Educação, Ciência e Tecnologia do Espírito Santo/Campus Ibatiba. Ibatiba, ES. E-mail: william.delarmelina@ifes.edu.br - ORCID: \\ 0000-0001-9347-9441
}

\section{Key words: \\ Lamiaceae \\ sewage sludge \\ substrate \\ seedling quality \\ seedling nutrition}

\begin{abstract}
A B S T R A C T
The use of organic wastes as primary source of nutrients can contribute to reducing the dependence on inputs, besides being a sustainable destination for these materials. This study aimed to evaluate the quality of Aegiphila sellowiana seedlings grown in substrates composed of different proportions of sewage sludge, organic wastes and vermiculite. Twenty six substrates (treatments) were tested, formulated from the mixture of sewage sludge with vermiculite and the wastes coconut fiber, fresh coffee straw, organic compost (fresh bovine manure and fresh coffee straw), carbonized rice husk and fresh rice husk, at the proportions of 100:0, 80:20, 60:40, 40:60 and 20:80 (sewage sludge:materials), and a control, composed of commercial substrate (Bioplant ${ }^{\circledR}$ ). At 120 days after sowing, the following morphological characteristics were determined: collar diameter, shoot height, dry matter (shoots, roots and total) and Dickson quality index (DQI) of all plants. Substrates formulated with sewage sludge and organic compost led to higher growth of seedlings (40\% SS:60\% OC and 20\% SS: $80 \%$ OC). Proportions of 20 to $40 \%$ sewage sludge and 60 to $80 \%$ organic compost are recommended for the production of $A$. sellowiana seedlings.
\end{abstract}

\section{Palavras-chave:}

Lamiaceae

lodo de esgoto

substrato

qualidade de mudas

nutrição de mudas

\section{Resíduos sólidos urbanos na produção de mudas de Aegiphila sellowiana Cham.}

\section{R E S U M O}

A utilização de resíduos orgânicos como fonte primária de nutrientes pode contribuir para a redução da dependência de insumos, além de ser uma destinação sustentável para esses materiais. Objetivou-se avaliar a qualidade de mudas de Aegiphila sellowiana desenvolvidas em substratos constituídos por proporções distintas de lodo de esgoto, resíduos orgânicos e vermiculita. Foram testados 26 substratos (tratamentos) formulados a partir da mistura de lodo de esgoto com vermiculita e os resíduos fibra de coco, palha de café in natura, composto orgânico (esterco bovino não curtido e palha de café in natura), casca de arroz carbonizada e casca de arroz in natura, nas proporções de 100:0, 80:20, 60:40, 40:60 e 20:80 (lodo de esgoto:materiais), e uma testemunha, constituída por substrato comercial (Bioplant ${ }^{\circledR}$ ). Aos 120 dias após a semeadura, foram determinadas as características morfológicas diâmetro do coleto, altura da parte aérea, massa seca (parte aérea, raízes e total) e calculado o índice de qualidade de Dickson (IQD) de todas as plantas. Os substratos formulados com lodo de esgoto e composto orgânico proporcionaram o maior crescimento das mudas (40\% LE:60\% CO e 20\% LE:80\%). Recomendam-se as proporções de 20 a $40 \%$ de lodo de esgoto e de 60 a $80 \%$ de composto orgânico para produzir mudas de A. sellowiana. 


\section{INTRODUCTION}

The increasing demand for projects of recovery of degraded areas (RDAs) increases the need to produce seedlings of forest species native to Brazil (Kratka \& Correia, 2015), opening new perspectives for species like Aegiphila sellowiana Cham. (Lamiaceae). Found in the Atlantic Forest region, A. sellowiana has great potential for RDAs due to its fast growth and production of large amount of fruits consumed by several bird species. In addition, it is a pioneer species and a heliophyte (Lorenzi, 2008), very useful to initiate the process of succession in open areas, exposed to solar radiation.

The use of industrial or urban wastes to compose substrates for production of seedlings of forest species has increased in the last years, being an economically viable alternative to guarantee the supply of raw material in the long term and at low cost (Caldeira et al., 2012a). In addition, it collaborates with the reduction of this environmental problem (Trazzi et al., 2014), since there is large production of this waste due to the populational growth.

Reuse of wastes such as sewage sludge becomes a low-cost option for its management and disposal, which are complex and expensive, besides the possibility of transforming this material that is currently seen as garbage in a commodity (Guerrini et al., 2017). Several studies point to the use of sewage sludge as a viable alternative to supply organic matter and nutrients in the formulation of substrates for production of seedlings of native forest species (Trazzi et al., 2014; Trigueiro \& Guerrini, 2014; Kratka \& Correia, 2015; Abreu et al., 2017). Sewage sludge can be an excellent unconventional source of nitrogen and potassium for wood production in nutritionally poor tropical soils (Abreu Júnior et al., 2017).

Considering the potentials of using sewage sludge in the formulation of substrates for production of good-quality seedlings and that its utilization brings environmental benefits and reduces the costs of seedling production, the present study aimed to evaluate the quality of A. sellowiana seedlings grown in substrates composed of different proportions of sewage sludge, organic wastes and vermiculite.

\section{Material ANd Methods}

A. sellowiana seedlings were produced between July and November 2012 in the nursery of the Experimental Area I at the Center of Agrarian Sciences and Engineering of the Federal University of Espírito Santo - UFES, in the municipality of Alegre - ES, Brazil (20 $45^{\prime}$ S; 41 $31^{\circ}$ ' W). The mean altitude of the experimental area is $120 \mathrm{~m}$ and the climate of the region is Cfa (rainy season in the summer and dry season in the winter), according to Köppen's classification. The mean annual temperature is $23{ }^{\circ} \mathrm{C}$ and mean annual rainfall is around 1,200 mm (Alvares et al., 2013).

The wastes used to produce the substrates were sewage sludge (SS), fresh rice husk (FRH), carbonized rice husk (CRH), organic compost (OC), coconut fiber (CF), fresh coffee straw (FCS), vermiculite (VER) and commercial substrate (CS) (Bioplant ${ }^{\circ}$ ), which, according to the manufacturer, is composed of pine bark, manure, sawdust, coconut fiber, vermiculite, agricultural gypsum, calcium carbonate, magnesium and additives (fertilizers).

The OC was produced using fresh bovine manure, from livestock activities of the Experimental Area I of the Center of Agrarian Sciences and Engineering of UFES, and fresh coffee straw donated by rural producers of the region of the Caparaó National Park, ES. These two wastes were mixed in equal volumes and remained for 60 days in open environment for biological stabilization. After this process, the material was passed through a 2-mm-mesh sieve for homogenization (Caldeira et al., 2008; Delarmelina et al., 2013). The SS came from the Sewage Treatment Station of the company Foz do Brasil S.A., located in the municipality of Cachoeiro de Itapemirim - ES. The SS was obtained after treatment in anaerobic filter, and the concentrations of chemical compounds and characteristics of this material are described in the study of Santos et al. (2014).

Twenty-six treatments were tested to compose the substrate: T1-100\% SS; T2-80\% SS/20\% CF; T3-60\% SS/40\% CF; T4$40 \%$ SS/60\% CF; T5-20\% SS/80\% CF; T6-80\% SS/20\% VER; T7-60\% SS/40\% VER; T8-40\% SS/60\% VER; T9-20\% SS/80\% VER; T10-80\% SS/20\% FCS; T11-60\% SS/40\% FCS; T12-40\% SS/60\% FCS; T13-20\% SS/80\% FCS; T14-80\% SS/20\% OC; T15-60\% SS/40\% OC; T16-40\% SS/60\% OC; T17-20\% SS/80\% OC; T18-80\% SS/20\% CRH; T19-60\% SS/40\% CRH; T20-40\% SS/60\% CRH; T21-20\% SS/80\% CRH; T22-80\% SS/20\% FRH; T23-60\% SS/40\% FRH; T24-40\% SS/60\% FRH; T25-20\% SS/80\% FRH; T26-100\% CS.

Physical characterization of the substrates was carried out in three samples (replicates) for each waste and treatment (MAPA, 2007). The experimental design was completely randomized, with five replicates of eight plants (sampling unit) and 26 treatments.

A. sellowiana seeds were obtained at the IPEF (Forest Science and Research Institute) from Capão Bonito - SP, 2012 season. Sowing was performed manually and each $280-\mathrm{cm}^{3}$ tube received four seeds. These tubes were placed on trays with capacity for 54 tubes. The trays were arranged on suspended beds at $80 \mathrm{~cm}$ height from the soil, in a shade house covered with $50 \%$ shading screen. To ensure the supply of nutrients to the seedlings, $750 \mathrm{~g}$ of ammonium sulfate $(20 \% \mathrm{~N}), 1667 \mathrm{~g}$ of single superphosphate $\left(18 \% \mathrm{P}_{2} \mathrm{O}_{5}\right)$ and $162 \mathrm{~g}$ of potassium chloride $\left(58 \% \mathrm{~K}_{2} \mathrm{O}\right)$ were added per $\mathrm{m}^{3}$ of substrate, according to the recommendation proposed by Gonçalves et al. (2000).

After emergence, when the seedlings had two pairs of leaves and were about $5 \mathrm{~cm}$ tall, thinning was performed, leaving only one seedling per tube. The plant which was most centralized in the tube and with greatest shoot growth was selected. The seedlings remained in the shade house (50\% shading) and were irrigated four times a day by an automatic irrigation system, twice in the morning and twice in the afternoon, totaling a 16-mm water depth per day. On rainy days, plants were not irrigated.

At 120 days after sowing, the following growth variables were measured: collar diameter $(\mathrm{D})$, shoot height $(\mathrm{H})$, root dry matter (RDM), shoot dry matter (SDM), total dry matter (TDM), H/D ratio, SDM/RDM ratio, and Dickson quality index (DQI). To obtain SDM and RDM, the plant parts were 
separately weighed after drying in forced air circulation oven at $65^{\circ} \mathrm{C}$, for a period of approximately $72 \mathrm{~h}$. DQI was obtained by the formula of Dickson et al. (1960).

After obtaining the dry matter, seedling shoots were ground in a knife mill, with 30 -mesh sieve, and three samples per treatment were collected for the determination of $\mathrm{N}, \mathrm{P}, \mathrm{K}, \mathrm{Ca}$, $\mathrm{Mg}$ and $\mathrm{S}$ contents, following the methodology described by Malavolta et al. (1997). Nutrient accumulation in the shoots of the seedlings was calculated by taking into account the contents of nutrients multiplied by their respective values of shoot dry matter.

The data were subjected to analysis of variance (ANOVA) $(p<0.05)$ and, when significant, the Scott-Knott test was applied to compare differences between means using the $\mathrm{R}$ software.

\section{Results AND Discussion}

In general, the treatments $\mathrm{T} 16-40 \% \mathrm{SS} / 60 \% \mathrm{OC}$ and T17-20\% SS/80\% OC, which used sewage sludge (SS) and organic compost (OC), stood out for producing A. sellowiana seedlings with better morphological characteristics (Table 1).

Evaluating the nutritional characteristics of the same substrates used here, Santos et al. (2014) reported that treatments formulated with SS and OC were considered as more adequate for the growth of seedings of forest species. The treatments T16-40\% SS/60\% OC and T17-20\% SS/80\% OC (Table 1) led to the highest means of diameter (D), shoot dry matter (SDM) and total dry matter (TDM). These two treatments and T15-60\% SS/40\% OC resulted in the highest values of root dry matter (RDM). The treatment T16 favored the growth of the seedlings in height $(\mathrm{H})$. The growth characteristics cited were superior in these treatments compared with the commercial substrate (T26-100\% CS).

Only the treatments with SS and OC (T14-80\% SS + 20\% OC, T15-60\% SS/40\% OC, T16-40\% SS + 60\% OC and T17$20 \%$ SS $+80 \%$ OC) and the T11-60\% SS $+40 \%$ FCS led to seedlings with $\mathrm{H}$ within the limit between 20 and $35 \mathrm{~cm}$ (Table 1 ), considered as ideal for seedlings of native forest species to be taken to the field (Gonçalves et al., 2000). As observed in the present study, the use of substrates formulated using SS and OC resulted in the best means of $\mathrm{H}$ in Sesbania virgata seedlings (Delarmelina et al., 2013). The growth in $\mathrm{H}$ of Mimosa scabrella seedlings was also low when the substrates combined SS with CRH (Kratz et al., 2013a).

Collar diameter is an important variable in the evaluation of seedling quality and is related to the capacity for establishment in the field (Silva et al., 2012). Gonçalves et al. (2000) consider D as adequate for seedlings of forest species when it is between 5 and $10 \mathrm{~mm}$. The substrates which met these specifications were all treatments formulated with SS plus OC or FCS and also the treatments T18-80\% SS/20\% $\mathrm{CRH}, \mathrm{T} 19-60 \% \mathrm{SS} / 40 \% \mathrm{CRH}$ and $\mathrm{T} 22-80 \% \mathrm{SS} / 20 \% \mathrm{FRH}$ (Table 1). As observed for $\mathrm{H}$, the highest means of $\mathrm{D}$ occurred in the substrates formulated with OC, which led to increase in substrate fertility, especially with respect to $\mathrm{P}, \mathrm{N}, \mathrm{Ca}$ and $\mathrm{Mg}$, as described by Santos et al. (2014).

The highest values of dry matter (SDM, RDM and TDM) (Table 1) were observed in the treatments which had contents above $40 \%$ of organic compost in substrate composition. Studying the growth of Sesbania virgata seedlings, Delarmelina et al. (2013) also found higher means of SDM in treatments formulated with organic compost.

Substrates formulated with up to $60 \%$ sewage sludge led to higher RDM accumulation (Gomes et al., 2013; Trigueiro \& Guerrini, 2014). Proportions higher than 60\% sewage sludge did not favor the increment in RDM, probably because of the undesirable alterations in the physical characteristics (density, macroporosity and microporosity) that the use of high concentrations of sewage sludge can cause in the substrate (Gomes et al., 2013).

Based on the $\mathrm{H} / \mathrm{D}$ ratio (Table 1 ), it can be observed that the treatment $\mathrm{T} 11-60 \% \mathrm{SS} / 40 \%$ FCS resulted in the highest mean, followed by the treatment T16-40\% SS/60\% OC. However, because of the disproportionate growth of $\mathrm{H}$ and $\mathrm{D}$, the ratio between these parameters in all treatments remained below that considered as ideal, from 5.4 to 8.1 (Carneiro, 1995). The H/D ratio, also called robustness coefficient (Gomes et al., 2002), varies with species, type and proportion of the substrate, container volume, management of seedlings in the nursery and age at which the seedling is evaluated (Gomes et al., 2013). This suggests further research to determine the ideal values of the $\mathrm{H} / \mathrm{D}$ ratio of native species (Delarmelina et al., 2013).

The treatments T11-60\% SS/40\% FCS and T17-20\% $\mathrm{SS} / 80 \%$ OC led to higher SDM/RDM ratio (Table 1) and were the only ones which reached the SDM/RDM ratio of 2:1, as suggested by Caldeira et al. (2008). These authors also point out that it is important to analyze this ratio when the seedlings are taken to the field, because their shoots should not be much greater than the roots, due to possible problems related to absorption of water for the shoots or lodging.

Seedlings in the treatments T15-60\% SS/40\% OC, T16$40 \%$ SS $/ 60 \%$ OC, T17-20\% SS/80\% OC and T18-80\% SS/20\% $\mathrm{CRH}$ had the highest values of DQI (Table 1). The higher the value of this parameter, the better the quality of the seedlings (Gomes et al., 2002), because they show low H/D ratio (without etiolation), balance in the SDM/RDM ratio (seedlings with root system capable of supplying the shoots) and high values of biomass (Abreu et al., 2017). Nonetheless, DQI may vary according to species, management of seedlings in the nursery, type and proportion of substrate, container volume, and mainly the age at which the seedling is evaluated (Caldeira et al., 2012b).

The treatment with $100 \%$ sewage sludge (T1) was not efficient for the production of A. sellowiana seedlings, as also observed in Schinus terebinthifolius Raddi seedlings (Caldeira et al., 2008). It can be noted that, as the percentage of sewage sludge increases in the substrate, there is an increase in bulk density and microporosity and reduction in macroporosity (Table 2), as observed in the study conducted by Kratz et al. (2013b). However, these characteristics are useful when sewage sludge is used in combination with low-density highmacroporosity wastes such as coconut fiber, rice husk and coffee straw. Despite having satisfactory chemical attributes, sewage sludge needs to be mixed with other components to provide balance between supply of nutrients and physical 
Table 1. Means and standard deviation for the growth variables of Aegiphila sellowiana seedlings produced in different substrates with sewage sludge

\begin{tabular}{|c|c|c|c|c|c|c|c|c|}
\hline Treatments & $\begin{array}{c}\mathrm{H} \\
(\mathrm{cm})\end{array}$ & $\underset{(\mathrm{mm})}{\mathrm{D}}$ & RDM & $\begin{array}{c}\text { SDM } \\
\left.\text { g plant }^{-1}\right)\end{array}$ & TDM & $H / D$ & SDM/RDM & DQI \\
\hline T1-100\% SS & $14.08 e^{\star} \pm 3.76$ & $5.59 c \pm 0.99$ & $1.73 c \pm 0.63$ & $2.03 \mathrm{e} \pm 0.81$ & $3.74 e^{\star} \pm 1.38$ & $2.53 \mathrm{~g} \pm 0.54$ & $1.14 d \pm 0.25$ & $1.02 b \pm 0.37$ \\
\hline T2-80\% SS/20\% CF & $12.84 f \pm 3.33$ & $4.85 d \pm 0.73$ & $1.29 \mathrm{e} \pm 0.43$ & $1.68 \mathrm{e} \pm 0.63$ & $2.97 f \pm 0.98$ & $2.65 \mathrm{~g} \pm 0.59$ & $1.31 \mathrm{c} \pm 0.45$ & $0.77 c \pm 0.26$ \\
\hline Т3-60\% SS/40\% CF & $10.52 \mathrm{~g} \pm 1.34$ & $.32 \mathrm{e} \pm 0.50$ & $0.96 \mathrm{e} \pm 0.20$ & $0.97 f \pm 0.18$ & $.94 \mathrm{~g} \pm 0.33$ & $2.45 \mathrm{~g} \pm 0.34$ & $1.03 d \pm 0.18$ & $0.57 d \pm 0.13$ \\
\hline T4-40\% SS/60\% CF & $9.35 \mathrm{~g} \pm 1.15$ & $.65 f \pm 0.43$ & $0.73 f \pm 0.19$ & $0.81 f \pm 0.16$ & $1.54 \mathrm{~g} \pm 0.33$ & $2.60 \mathrm{~g} \pm 0.44$ & $1.15 d \pm 0.21$ & $0.42 d \pm 0.13$ \\
\hline$\% \mathrm{CF}$ & $g \pm 1.15$ & $71 \mathrm{~g} \pm 0.39$ & $7 f \pm 0.11$ & $0.36 \mathrm{~g} \pm 0.13$ & $.73 \mathrm{~h} \pm 0.23$ & $3.50 \mathrm{e} \pm$ & $0.96 \mathrm{e} \pm 0.18$ & $0.17 \mathrm{e} \pm 0.07$ \\
\hline & $51 \mathrm{f} \pm 1.99$ & $1 \mathrm{e} \pm 0.70$ & $1.25 e \pm 0.47$ & $1.59 \mathrm{e} \pm 0.56$ & $83 f \pm 0.98$ & 0.40 & $1.36 \mathrm{c}$ & $0.71 c \pm 0.28$ \\
\hline T7-60\% SS/40\% VER & $5.75 e \pm 3.01$ & $59 \mathrm{e} \pm 0.47$ & $1.69 c \pm 0.44$ & $1.86 \mathrm{e} \pm 0.28$ & 3.56 e \pm 0.60 & $3.46 \mathrm{e} \pm 0.68$ & $1.16 d \pm 0.34$ & $0.81 c \pm 0.23$ \\
\hline T8-40\% SS/60\% VER & $11.55 f \pm 1.85$ & $4.61 \mathrm{e} \pm 0.52$ & $1.45 d \pm 0.52$ & $1.63 \mathrm{e} \pm 0.48$ & $3.08 f \pm 0.94$ & $2.53 \mathrm{~g} \pm 0.43$ & $1.20 d \pm 0.37$ & $0.87 c \pm 0.35$ \\
\hline $0 \%$ VER & $11.58 f \pm 1.85$ & $4.45 \mathrm{e} \pm 0.55$ & $1.37 d \pm 0.23$ & $1.30 f \pm 0.46$ & $2.67 f \pm 0.62$ & $2.63 \mathrm{~g} \pm 0.48$ & $0.94 \mathrm{e} \pm 0.26$ & $0.76 c \pm 0.20$ \\
\hline & $7 \mathrm{e} \pm 3$ & $8 c \pm 1$ & $88 d \pm 0.86$ & $2.17 d \pm 1.04$ & $5 e \pm$ & $2.92 f=$ & & $0.89 b$ \\
\hline & $c \pm 3$ & & $d \pm$ & $61 d \pm 0.95$ & & & & $0.62 \mathrm{~d}$ \\
\hline & $3.84 d \pm 3.25$ & $.78 c \pm 1.02$ & $1.84 c \pm 0.78$ & $2.95 c \pm 0.84$ & $9 c \pm 1.58$ & 3.33 e \pm 0.69 & 0.56 & $1.02 b \pm 0.49$ \\
\hline $80 \%$ FCS & $17.08 d \pm 3.13$ & $5.37 c \pm 1.00$ & $1.77 \mathrm{c} \pm 0.80$ & $2.45 d \pm 0.89$ & $4.22 d \pm 1.65$ & $3.22 f \pm 0.57$ & $1.52 \mathrm{c} \pm 0.37$ & $0.94 b \pm 0.45$ \\
\hline & $25.16 c \pm 5.86$ & $5.89 c \pm 1.06$ & $2.15 b \pm 0.71$ & $3.25 c \pm 1.10$ & $5.40 c \pm 1.52$ & $4.30 c \pm 0.95$ & $1.59 c \pm 0.44$ & $0.96 b \pm 0.33$ \\
\hline & $0 \pm 7$ & $b \pm 1$ & $\mathrm{a} \pm$ & .90 & 71 & & & $1.22 \mathrm{a}$ \\
\hline & $a \pm 5.06$ & $2 \mathrm{a} \pm 0.70$ & $2.72 \mathrm{a} \pm 0.82$ & $5.25 a \pm 1.67$ & $a \pm 2.36$ & 0.69 & & $1.24 \mathrm{a} \pm 0.39$ \\
\hline & \pm 6.82 & $a \pm 1.53$ & $a \pm 1.35$ & $a \pm 2.61$ & $a \pm 3.10$ & 0.75 & & $1.35 a \pm 0.72$ \\
\hline$\% \mathrm{CRH}$ & $18.30 d \pm 3.30$ & $5.77 \mathrm{c} \pm 0.75$ & $2.24 b \pm 0.50$ & $2.88 c \pm 0.63$ & $5.12 c \pm 1.04$ & $3.22 f \pm 0.72$ & $1.32 \mathrm{c} \pm 0.26$ & $1.15 a \pm 0.31$ \\
\hline & $16.61 d \pm 3.45$ & $33 c \pm 0.71$ & $1.86 c \pm 0.49$ & $2.53 d \pm 0.77$ & $4.40 d \pm 1.16$ & $3.12 f \pm 0.57$ & \pm 0.33 & $1.00 b \pm 0.28$ \\
\hline & $e \pm 2.28$ & & $d \pm$ & \pm 0.47 & & & & $0.81 c \pm 0.25$ \\
\hline & & 13 & $9 \mathrm{e} \pm 0.23$ & $.11 \mathrm{f} \pm 0.20$ & 36 & 0.37 & & $0.60 d \pm 0.11$ \\
\hline & $d \pm 2.91$ & $c \pm 0$ & $86 c \pm 0.51$ & $.43 d \pm 0.71$ & $.28 d \pm 1.12$ & 0.58 & 0.40 & $0.91 b \pm 0.27$ \\
\hline 6 FRH & $13.30 \mathrm{e} \pm 1.68$ & $4.82 d \pm 0.65$ & $1.55 d \pm 0.31$ & $1.75 \mathrm{e} \pm 0.37$ & $3.30 \mathrm{e} \pm 0.58$ & $2.79 \mathrm{~g} \pm 0.43$ & $1.16 d \pm 0.26$ & $0.85 c \pm 0.21$ \\
\hline$/ 60 \% \mathrm{FRH}$ & $6.56 h \pm 1.27$ & $2.61 \mathrm{~g} \pm 0.27$ & $0.45 f \pm 0.11$ & $0.57 \mathrm{~g} \pm 0.11$ & $1.02 h \pm 0.21$ & $2.52 \mathrm{~g} \pm 0.45$ & $1.30 \mathrm{c} \pm 0.23$ & $0.27 e \pm 0.06$ \\
\hline$/ 80 \%$ FRH & $4.47 \mathrm{~h} \pm 1.06$ & $2.11 \mathrm{~h} \pm 0.34$ & $0.17 f \pm 0.07$ & $0.19 \mathrm{~g} \pm 0.08$ & $0.36 h \pm 0.15$ & $2.14 \mathrm{~g} \pm 0.45$ & $1.15 d \pm 0.25$ & $0.11 \mathrm{e} \pm 0.05$ \\
\hline & $10.07 \mathrm{~g} \pm 2.47$ & $4.26 \mathrm{e} \pm 0.72$ & $1.41 d \pm 0.45$ & $0.93 f \pm 0.43$ & $2.34 f \pm 0.80$ & $2.37 \mathrm{~g} \pm 0.45$ & 0.66 e \pm 0.19 & $0.78 c \pm 0.23$ \\
\hline & $\star *$ & $\star \star$ & $\star \star$ & ** & $\star \star$ & $\star \star$ & $\star *$ & $\star \star$ \\
\hline $\mathrm{CV}^{* \star *}$ & 48.65 & 29.77 & 57.46 & 74.24 & 64.33 & 30.41 & 44.73 & 54.90 \\
\hline
\end{tabular}

SS - Sewage sludge; CF - Coconut fiber; VER - Vermiculite; FCS - Fresh coffee straw; OC - Organic compost; CRH - Carbonized rice husk; FRH - Fresh rice husk; CS - Commercial substrate; H - Shoot height; D - Collar diameter; RDM - Root dry matter; SDM - Shoot dry matter; TDM - Total dry matter; DQI - Dickson quality index * Means followed by the same letter, in the column, do not differ statistically by Scott-Knott test. ${ }^{* \star}$ Significant $(p<0.05) ;{ }^{* *}$ Coefficient of variation

Table 2. Means and standard deviation for the physical characteristics of the treatments evaluated

\begin{tabular}{|c|c|c|c|c|c|}
\hline \multirow{2}{*}{ Treatment } & \multirow{2}{*}{$\begin{array}{c}\text { Bulk density } \\
\left(\mathrm{g} \mathrm{cm}^{-3}\right)\end{array}$} & Total porosity & Macroporosity & Microporosity & Available water \\
\hline & & \multicolumn{4}{|r|}{ 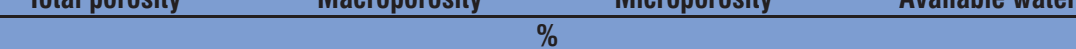 } \\
\hline T1-100\% SS & $0.70 a^{*} \pm 0.01$ & $78.86 c \pm 2.10$ & $18.95 f \pm 2.53$ & $59.91 b \pm 0.79$ & $33.26 a \pm 0.90$ \\
\hline T2-80\% SS/20\% CF & $0.62 b \pm 0.01$ & $78.74 c \pm 1.13$ & $16.03 g \pm 1.00$ & $62.70 a \pm 0.27$ & $34.74 a \pm 0.27$ \\
\hline T3-60\% SS/40\% CF & $0.50 c \pm 0.01$ & $83.13 b \pm 1.17$ & $19.44 \mathrm{f} \pm 1.21$ & $63.69 a \pm 0.22$ & $35.95 a \pm 0.19$ \\
\hline T4-40\% SS/60\% CF & $0.39 e \pm 0.01$ & $85.94 b \pm 1.52$ & $21.17 f \pm 0.84$ & $64.77 a \pm 0.98$ & $37.04 a \pm 0.48$ \\
\hline T5-20\% SS/80\% CF & $0.29 g \pm 0.00$ & $85.70 b \pm 3.85$ & 22.42 e \pm 1.86 & $63.28 a \pm 2.00$ & $35.40 \mathrm{a} \pm 1.51$ \\
\hline T6-80\% SS/20\% VER & $0.68 a \pm 0.01$ & $77.28 c \pm 1.68$ & $15.84 \mathrm{~g} \pm 1.83$ & $61.44 b \pm 0.36$ & $29.61 b \pm 0.37$ \\
\hline T7-60\% SS/40\% VER & $0.58 b \pm 0.01$ & $76.77 c \pm 0.51$ & $15.85 \mathrm{~g} \pm 0.75$ & $60.92 b \pm 0.43$ & $24.74 c \pm 0.26$ \\
\hline T8-40\% SS/60\% VER & $0.42 \mathrm{e} \pm 0.02$ & $75.99 d \pm 4.04$ & $19.36 f \pm 0.86$ & $56.62 c \pm 3.30$ & $16.76 d \pm 0.80$ \\
\hline T9-20\% SS/80\% VER & $0.30 \mathrm{~g} \pm 0.01$ & $75.77 d \pm 1.75$ & $19.68 f \pm 0.89$ & $56.09 \mathrm{c} \pm 1.78$ & $12.34 \mathrm{e} \pm 0.33$ \\
\hline T10-80\% SS/20\% FCS & $0.69 a \pm 0.00$ & $73.51 d \pm 0.51$ & $19.86 f \pm 0.43$ & $53.65 c \pm 0.09$ & $25.17 c \pm 0.60$ \\
\hline T11-60\% SS/40\% FCS & $0.58 b \pm 0.02$ & $72.19 d \pm 1.59$ & $28.15 d \pm 1.57$ & 44.03 e \pm 0.95 & $14.20 d \pm 1.19$ \\
\hline T12-40\% SS/60\% FCS & $0.47 d \pm 0.07$ & $72.16 d \pm 1.98$ & $37.65 c \pm 1.06$ & $34.50 \mathrm{~g} \pm 1.34$ & 10.14 e \pm 0.96 \\
\hline T13-20\% SS/80\% FCS & $0.29 \mathrm{~g} \pm 0.05$ & $74.71 d \pm 3.33$ & $46.79 b \pm 3.23$ & $27.91 h \pm 0.20$ & $04.33 f \pm 0.81$ \\
\hline $\mathrm{T} 14-80 \% \mathrm{SS} / 20 \%$ OC & $0.69 a \pm 0.02$ & $77.09 \mathrm{c} \pm 0.70$ & $21.20 f \pm 2.54$ & $55.89 c \pm 1.99$ & $27.03 c \pm 1.60$ \\
\hline $\mathrm{T} 15-60 \% \mathrm{SS} / 40 \%$ OC & $0.68 a \pm 0.01$ & $77.46 c \pm 0.25$ & $23.27 \mathrm{e} \pm 0.38$ & $54.18 c \pm 0.19$ & $23.60 c \pm 0.56$ \\
\hline $\mathrm{T} 16-40 \% \mathrm{SS} / 60 \%$ OC & $0.67 a \pm 0.02$ & $78.17 c \pm 1.00$ & $22.44 \mathrm{e} \pm 2.25$ & $55.73 c \pm 1.47$ & $25.78 c \pm 0.44$ \\
\hline $\mathrm{T} 17-20 \% \mathrm{SS} / 80 \%$ OC & $0.64 a \pm 0.00$ & $80.45 c \pm 0.65$ & $26.74 d \pm 0.48$ & $53.71 c \pm 0.24$ & $22.89 c \pm 0.23$ \\
\hline T18-80\% SS/20\% CRH & $0.60 b \pm 0.01$ & $78.46 c \pm 1.16$ & $17.97 \mathrm{~g} \pm 0.88$ & $60.49 b \pm 1.45$ & $35.95 a \pm 1.33$ \\
\hline T19-60\% SS/40\% CRH & $0.52 c \pm 0.01$ & $79.78 c \pm 1.32$ & $25.03 d \pm 1.53$ & $54.74 \mathrm{c} \pm 1.42$ & $33.54 \mathrm{a} \pm 1.37$ \\
\hline T20-40\% SS/60\% CRH & $0.41 e \pm 0.01$ & $75.22 d \pm 0.79$ & $26.71 d \pm 2.22$ & $48.50 d \pm 1.94$ & $30.52 b \pm 2.03$ \\
\hline T21-20\% SS/80\% CRH & $0.33 f \pm 0.01$ & $56.43 f \pm 1.99$ & $17.88 \mathrm{~g} \pm 3.10$ & $38.55 f \pm 2.57$ & $22.66 c \pm 2.73$ \\
\hline T22-80\% SS/20\% FRH & $0.61 b \pm 0.02$ & $77.90 \mathrm{c} \pm 1.16$ & $22.74 \mathrm{e} \pm 2.22$ & $55.16 c \pm 1.20$ & $29.91 b \pm 1.27$ \\
\hline T23-60\% SS/40\% FRH & $0.57 b \pm 0.01$ & 68.98 e \pm 3.24 & $23.52 \mathrm{e} \pm 2.99$ & $45.46 \mathrm{e} \pm 0.95$ & $21.32 c \pm 0.50$ \\
\hline T24-40\% SS/60\% FRH & $0.43 e \pm 0.05$ & $79.58 c \pm 3.99$ & $45.14 b \pm 4.74$ & $34.43 \mathrm{~g} \pm 1.19$ & $11.62 \mathrm{e} \pm 1.96$ \\
\hline T25-20\% SS/80\% FRH & $0.26 \mathrm{~g} \pm 0.03$ & $75.35 d \pm 2.45$ & $53.48 \mathrm{a} \pm 2.68$ & $21.86 \mathrm{i} \pm 0.25$ & $0.40 f \pm 0.13$ \\
\hline T26-100\% CS & $0.60 b \pm 0.01$ & $89.45 a \pm 1.49$ & $40.19 c \pm 0.96$ & $49.25 d \pm 1.64$ & $23.29 c \pm 2.41$ \\
\hline $\mathrm{F}$ & $\star \star$ & $\star \star$ & $\star \star$ & $\star \star$ & $\star \star$ \\
\hline CV $(\%)^{\star \star *}$ & 27.65 & 8.17 & 40.04 & 22.29 & 42.93 \\
\hline
\end{tabular}

SS - Sewage sludge; CF - Coconut fiber; VER - Vermiculite; FCS - Fresh coffee straw; OC - Organic compost; CRH - Carbonized rice husk; FRH - Fresh rice husk; CS - Commercial substrate; *Means followed by the same letter, in the column, do not differ statistically by Scott-Knott test. ${ }^{*}$ Significant $(p<0.05)$; ${ }^{* *}$ Coefficient of variation

conditions, such as aeration and water retention (Caldeira et al., 2012b).
The commercial substrate (T26) was not considered as ideal for the production of A. sellowiana seedlings (Table 1), 
Table 3. Means and standard deviation of nutrient accumulation in the shoots of Aegiphila sellowiana seedlings produced in different substrates

\begin{tabular}{|c|c|c|c|c|c|c|}
\hline \multirow{2}{*}{ Treatment } & $\mathrm{N}$ & $\mathbf{P}$ & $\mathrm{K}$ & $\mathrm{Ca}$ & $\mathrm{Mg}$ & $S$ \\
\hline & \multicolumn{6}{|c|}{$\left(\mathrm{g} \mathrm{kg}^{-1}\right)$} \\
\hline T1-100\% SS & $52.26 \mathrm{e} \pm 1.23$ & $9.63 * g \pm 0.47$ & $12.64 \mathrm{~g} \pm 0.98$ & $22.48 \mathrm{e} \pm 1.46$ & $6.21 \mathrm{~h} \pm 0.35$ & $4.28 \mathrm{e} \pm 0.26$ \\
\hline T2-80\% SS/20\% CF & $49.58 f \pm 0.17$ & $12.79 f \pm 0.38$ & $11.38 \mathrm{~g} \pm 1.35$ & $17.86 f \pm 2.49$ & $6.83 h \pm 0.17$ & $4.45 e \pm 0.19$ \\
\hline T3-60\% SS/40\% CF & $31.58 \mathrm{i} \pm 1.66$ & $10.23 \mathrm{~g} \pm 0.67$ & $8.73 h \pm 0.02$ & $10.59 \mathrm{~g} \pm 1.28$ & $3.67 \mathrm{i} \pm 0.06$ & $2.56 \mathrm{~h} \pm 0.05$ \\
\hline T4-40\% SS/60\% CF & $21.44 j \pm 0.53$ & $8.35 \mathrm{~h} \pm 0.60$ & $9.75 h \pm 1.80$ & $7.77 \mathrm{~h} \pm 0.94$ & $2.92 \mathrm{i} \pm 0.29$ & $1.84 i \pm 0.05$ \\
\hline T5-20\% SS/80\% CF & $7.52 \mathrm{~m} \pm 1.07$ & $3.41 \mathrm{j} \pm 0.26$ & $3.23 \mathrm{j} \pm 0.54$ & $3.29 i \pm 0.30$ & $1.58 \mathrm{j} \pm 0.15$ & $0.71 k \pm 0.02$ \\
\hline T6- $80 \%$ SS/20\% VER & $40.32 \mathrm{~g} \pm 0.78$ & $12.35 \mathrm{f} \pm 1.69$ & $11.24 \mathrm{~g} \pm 1.08$ & $17.30 \mathrm{f} \pm 1.17$ & $8.03 \mathrm{~g} \pm 0.75$ & $3.59 g \pm 0.08$ \\
\hline T7-60\% SS/40\% VER & $41.24 \mathrm{~g} \pm 1.66$ & $12.53 \mathrm{f} \pm 2.70$ & $12.79 \mathrm{~g} \pm 1.27$ & $18.99 \mathrm{f} \pm 1.39$ & $14.86 \mathrm{c} \pm 1.10$ & $3.99 f \pm 0.23$ \\
\hline T8-40\% SS/60\% VER & $33.48 i \pm 0.32$ & $9.21 \mathrm{~g} \pm 0.09$ & $9.30 \mathrm{~h} \pm 0.14$ & $10.44 \mathrm{~g} \pm 0.47$ & $12.34 d \pm 0.51$ & $2.74 \mathrm{~h} \pm 0.16$ \\
\hline T9-20\% SS/80\% VER & $23.74 j \pm 0.57$ & $7.69 h \pm 0.07$ & $8.39 h \pm 0.72$ & $8.06 h \pm 0.23$ & $9.08 f \pm 0.56$ & $1.79 \mathrm{i} \pm 0.18$ \\
\hline T10-80\% SS/20\% FCS & $37.00 h \pm 3.59$ & $9.99 \mathrm{~g} \pm 2.83$ & $15.11 \mathrm{f} \pm 2.90$ & $20.18 e \pm 5.17$ & $6.42 h \pm 1.31$ & $3.13 \mathrm{~g} \pm 1.08$ \\
\hline T11-60\% SS/40\% FCS & $46.84 \mathrm{f} \pm 1.81$ & $15.28 \mathrm{e} \pm 0.22$ & $19.29 \mathrm{e} \pm 1.21$ & $28.14 c \pm 0.56$ & $7.62 \mathrm{~g} \pm 0.83$ & $3.57 \mathrm{~g} \pm 0.31$ \\
\hline T12-40\% SS/60\% FCS & $55.07 \mathrm{e} \pm 0.22$ & $13.19 f \pm 0.50$ & $17.50 \mathrm{e} \pm 2.02$ & $29.79 c \pm 0.86$ & $9.36 f \pm 0.25$ & $4.45 \mathrm{e} \pm 0.54$ \\
\hline T13-20\% SS/80\% FCS & $48.09 f \pm 0.78$ & $12.54 f \pm 0.59$ & $16.73 f \pm 1.82$ & $24.83 d \pm 0.08$ & $10.12 f \pm 0.57$ & $3.40 \mathrm{~g} \pm 0.11$ \\
\hline $\mathrm{T} 14-80 \% \mathrm{SS} / 20 \%$ OC & $69.31 d \pm 0.53$ & $19.36 d \pm 2.56$ & $22.26 d \pm 1.72$ & $41.08 b \pm 2.56$ & $11.24 \mathrm{e} \pm 0.96$ & $5.42 \mathrm{~d} \pm 0.62$ \\
\hline T15-60\% SS/40\% OC & $88.57 c \pm 2.31$ & $26.74 c \pm 0.67$ & $29.04 \mathrm{c} \pm 1.94$ & $43.55 b \pm 3.03$ & $14.13 c \pm 1.20$ & $6.68 c \pm 0.43$ \\
\hline T16-40\% SS/60\% OC & $120.70 \mathrm{a} \pm 3.58$ & $35.60 \mathrm{a} \pm 2.89$ & $34.66 \mathrm{a} \pm 2.43$ & $59.26 a \pm 0.95$ & $25.52 b \pm 1.00$ & $9.46 a \pm 0.33$ \\
\hline T17-20\% SS/80\% OC & $109.31 b \pm 8.36$ & $29.07 b \pm 1.43$ & $31.64 b \pm 2.28$ & $56.19 a \pm 1.40$ & $29.92 \mathrm{a} \pm 0.87$ & $8.80 b \pm 0.32$ \\
\hline T18-80\% SS/20\% CRH & 55.05 e \pm 3.29 & $16.20 \mathrm{e} \pm 1.03$ & $16.35 f \pm 0.35$ & $30.15 c \pm 2.20$ & $8.33 \mathrm{~g} \pm 0.72$ & $4.64 \mathrm{e} \pm 0.23$ \\
\hline T19-60\% SS/40\% CRH & $51.57 \mathrm{e} \pm 0.27$ & $15.55 e \pm 0.70$ & $15.75 f \pm 0.64$ & $27.59 c \pm 4.68$ & $7.94 \mathrm{~g} \pm 0.52$ & $4.91 d \pm 0.37$ \\
\hline T20-40\% SS/60\% CRH & $37.51 \mathrm{~h} \pm 0.43$ & $11.52 \mathrm{f} \pm 0.15$ & $11.57 \mathrm{~g} \pm 2.24$ & $22.45 e \pm 0.80$ & $5.62 \mathrm{~h} \pm 0.07$ & $3.39 g \pm 0.18$ \\
\hline T21-20\% SS/80\% CRH & $19.22 k \pm 1.24$ & $4.98 \mathrm{i} \pm 0.11$ & $6.63 h \pm 0.28$ & $11.20 \mathrm{~g} \pm 1.05$ & $3.18 \mathrm{i} \pm 0.15$ & $1.88 \mathrm{i} \pm 0.16$ \\
\hline T22-80\% SS/20\% FRH & $43.37 \mathrm{~g} \pm 1.01$ & $12.58 \mathrm{f} \pm 1.12$ & $13.53 \mathrm{~g} \pm 0.94$ & $28.14 \mathrm{c} \pm 0.92$ & $7.07 h \pm 0.43$ & $4.57 \mathrm{e} \pm 0.26$ \\
\hline $\mathrm{T} 23-60 \% \mathrm{SS} / 40 \% \mathrm{FRH}$ & $36.59 h \pm 0.63$ & $10.61 \mathrm{~g} \pm 0.26$ & $10.65 \mathrm{~g} \pm 0.89$ & $21.69 \mathrm{e} \pm 2.04$ & $6.51 \mathrm{~h} \pm 0.07$ & $4.07 f \pm 0.15$ \\
\hline T24-40\% SS/60\% FRH & $15.85 k \pm 0.39$ & $5.18 i \pm 0.02$ & $4.34 i \pm 0.22$ & $6.82 h \pm 0.25$ & $1.97 j \pm 0.08$ & $1.45 j \pm 0.13$ \\
\hline T25-20\% SS/80\% FRH & $5.00 m \pm 0.33$ & $1.92 \mathrm{j} \pm 0.02$ & $1.42 \mathrm{j} \pm 0.09$ & $1.98 \mathrm{i} \pm 0.04$ & $0.78 k \pm 0.02$ & $0.49 k \pm 0.01$ \\
\hline T26-100\% CS & $11.66 \mid \pm 0.59$ & $3.08 j \pm 0.18$ & $5.34 i \pm 0.50$ & $12.68 \mathrm{~g} \pm 0.55$ & $2.14 j \pm 0.07$ & $0.97 k \pm 0.13$ \\
\hline $\mathrm{F}$ & $\star \star$ & $\star \star$ & $\star \star$ & $\star \star \star$ & $\star \star$ & $\star \star$ \\
\hline $\mathrm{CV}(\%)^{\star \star \star}$ & 62.91 & 61.96 & 59.84 & 65.83 & 78.04 & 58.41 \\
\hline
\end{tabular}

SS - Sewage sludge; CF - Coconut fiber; VER - Vermiculite; FCS - Fresh coffee straw; OC - Organic compost; CRH - Carbonized rice husk; FRH - Fresh rice husk; CS - Commercial substrate; *Means followed by the same letter, in the column, do not differ statistically by Scott-Knott test. ${ }^{*}$ Significant $(p<0.05)$; ${ }^{* *}$ Coefficient of variation

because these seedlings did not show minimum $\mathrm{H}$ of $20 \mathrm{~cm}$ and $\mathrm{H}$ between 5 and $10 \mathrm{~mm}$ (Gonçalves et al., 2000). This result can be related to physical factors, such as total porosity of $89.45 \%$ (Table 2), which exceeded the reference values considered as ideal. Caldeira et al. (2013) observed that high values of total porosity (above $85 \%$ ) in the commercial substrate can hamper the initial growth of Chamaecrista desvauxii (Collad.) seedlings, as observed in the present study. Although the highest means of $\mathrm{P}, \mathrm{Ca}$ and $\mathrm{Mg}$ contents were found in the commercial substrate (Santos et al., 2014), seedlings in this treatment showed RDM higher than SDM (Table 1), which can be related to the water availability of the substrate.

Corroborating the results of SDM for A. sellowiana seedlings, the treatments formulated with SS and OC led to greater accumulation of macronutrients in their shoots (Table 3).

In the treatment $\mathrm{T} 16-40 \% \mathrm{SS} / 60 \%$ OC, there was greater accumulation of N, P, K and S in the shoots of the seedlings. Still considering these macronutrients, the second highest mean was found in T17-20\% SS/80\% OC. For Mg, superior accumulations were found in T17-20\% SS/80\% OC, followed by $\mathrm{T} 16-40 \% \mathrm{SS} / 60 \%$ OC. For Ca, there was no difference in the accumulation between $\mathrm{T} 16-40 \% \mathrm{SS} / 60 \%$ OC and T17$20 \%$ SS $/ 80 \%$ OC. The treatments T5-20\% SS/80\% CF, T24$40 \%$ SS/60\% FRH, T25-20\% SS/80\% FRH and T26-100\% CS led to lowest accumulations of all nutrients evaluated.

In the present study, the decreasing order of accumulation of nutrients in the shoots was $\mathrm{N}>\mathrm{Ca}>\mathrm{K}>\mathrm{P}>\mathrm{Mg}>\mathrm{S}$. Highest $\mathrm{N}$ accumulation in the shoots of the seedlings was observed in the substrate formulated with $60 \%$ OC (Table 3) because this treatment led to higher mean of SDM (Rocha et al., 2013). Ca contents in the tissues of the seedlings are correlated with the available contents of this nutrient in the substrate, which explains its higher accumulation in the shoots, in general, under higher proportions of sewage sludge.

The treatments T24-40\% SS/60\% FRH and T25-20\% SS/80\% FRH did not allow adequate growth of $A$. sellowiana seedlings. These treatments led to the lowest means of $\mathrm{H}, \mathrm{D}$ and dry matter (Table 1) and, therefore, should be avoided. Lowest accumulations of all nutrients evaluated in the shoots were also observed in these treatments. This result may be linked to the low values of available water (AW) (Table 2) found in these treatments.

Sewage sludge proved to have positive effects on the growth of A. sellowiana seedlings. This waste improved substrate fertility with increment in the contents of nutrients, especially P and N (Santos et al., 2014; Trigueiro \& Guerrini, 2014; Abreu et al., 2017). However, sewage sludge requires the addition of other components to provide balance between supply of nutrients and physical conditions, such as aeration and water retention (Kratz et al., 2013a). The quality of seedlings produced with substrates containing sewage sludge in their composition can be confirmed by conducting experiments to analyze their performance in the field.

\section{Conclusions}

1. Sewage sludge alone is not an adequate substrate for the production of $A$. sellowiana seedlings. 
2. Proportions of $40 \%$ SS/60\% OC and $20 \%$ SS/80\% OC constitute an adequate substrate for the production of $A$. sellowiana seedlings.

\section{ACKNOWLEDGMENT}

To the Coordenação de Aperfeiçoamento de Pessoal de Nível Superior (CAPES) for granting the scholarship to the second author.

\section{Literature Cited}

Abreu, A. H. M. de; Marzola, L. B.; Melo, L. A. de; Leles, P. S. dos S.; Abel, E. L. S.; Alonso, J. M. Urban solid waste in the production of Lafoensia pacari seedlings. Revista Brasileira de Engenharia Agrícola e Ambiental, v.21, p.83-87, 2017. https:// doi.org/10.1590/1807-1929/agriambi.v21n2p83-87

Abreu Júnior, C. H.; Firme, L. P.; Maldonado, C. A. B.; Moraes Neto, S. P. de; Alves, M. C.; Muraoka, T.; Boaretto, A. E.; Gava, J. L.; He, Z.; Nogueira, T. A. R.; Capra, G. F. Fertilization using sewage sludge in unfertile tropical soils increased wood production in Eucalyptus plantations. Journal of Environmental Management, v.203, p.5158, 2017. https://doi.org/10.1016/j.jenvman.2017.07.074

Alvares, C. A.; Stape, J. L.; Sentelhas, P. C.; Gonçalves, J. L. de M.; Sparovek, G. Köppen's climate classification map for Brazil. Meteorologische Zeitschrift, v.22, p.711-728, 2013. https://doi. org/10.1127/0941-2948/2013/0507

Caldeira, M. V. W.; Delarmelina, W. M.; Faria, J. C. T.; Juvanhol, R. S. Substratos alternativos na produção de mudas de Chamaecrista desvauxii. Revista Árvore, v.37, p.31-39, 2013. https://doi. org/10.1590/S0100-67622013000100004

Caldeira, M. V. W.; Delarmelina, W. M.; Lube, S. G.; Gomes, D. R.; Gonçalves, E. de O.; Alves, A. F. Biossólido na composição de substrato para a produção de mudas de Tectona grandis. Floresta, v.42, p.77-84, 2012a. https://doi.org/10.5380/rf.v42i1.26302

Caldeira, M. V. W.; Peroni, L.; Gomes, D. R.; Delarmelina, W. M.; Trazzi, P. A. Diferentes proporções de biossólido na composição de substratos para a produção de mudas de timbó (Ateleia glazioveana Baill). Scientia Forestalis, v.40, p.15-22, 2012b.

Caldeira, M. V. W.; Rosa, G. N. da; Fenilli, T. A. B.; Harbs, R. M. P. Composto orgânico na produção de mudas de aroeira vermelha. Scientia Agraria, v.9, p.27-33, 2008. https://doi.org/10.5380/rsa. v9i1.9898

Carneiro, J. G. de A. Produção e controle de qualidade de mudas florestais. Curitiba: Universidade Federal do Paraná, 1995. 451p.

Delarmelina, W. M.; Caldeira, M. V. W.; Faria, J. C. T.; Gonçalves, E. de O. Uso de lodo de esgoto e resíduos orgânicos no crescimento de mudas de Sesbania virgata (Cav.) Pers. Revista Agro@mbiente On-line, v.7, p.184-192, 2013.

Dickson, A.; Leaf, A. L.; Hosner, J. F. Quality appraisal of while spruce and white pine seedling stock in nurseries. Forestry Chronicle, v.36, p.11-13, 1960.

Gomes, D. R.; Caldeira, M. V. W.; Delarmelina, W. M.; Gonçalves, E. de O.; Trazzi, P. A. Lodo de esgoto como substrato para produção de mudas de Tectona grandis L. Cerne, v.19, p.123-131, 2013. https://doi.org/10.1590/S0104-77602013000100015
Gomes, J. M.; Couto, L.; Leite, H. G.; Xavier, A.; Garcia, S. L. R. Parâmetros morfológicos na avaliação da qualidade de mudas de Eucalyptus grandis. Revista Árvore, v.26, p.655-664, 2002. https:// doi.org/10.1590/S0100-67622002000600002

Gonçalves, J. L. M.; Santarelli, E. G.; Moraes Neto, S. P.; Manara, M. P. Produção de mudas de espécies nativas: Substrato, nutrição, sombreamento e fertilização. In: Gonçalves, J. L. M.; Benedetti, V. (eds.). Nutrição e fertilização florestal. Piracicaba: IPEF, 2000. Cap.11, p.309-350.

Guerrini, I. A.; Croce, C. G. G.; Bueno, O. de C.; Jacon, C. P. R. P.; Nogueira, T. A. R.; Fernandes, D. M.; Ganga, A.; Capra, G. F. Composted sewage sludge and steel mill slag as potential amendments for urban soils involved in afforestation programs. Urban Forestry \& Urban Greening, v.22, p.93-104, 2017. https://doi.org/10.1016/j. ufug.2017.01.015

Kratka, P. C.; Correia, C. R. M. de A. Crescimento inicial de aroeira do sertão (Myracrodruon urundeuva Allemão) em diferentes substratos. Revista Árvore, v.39, p.551-559, 2015. https://doi.org/10.1590/010067622015000300016

Kratz, D.; Wendling, I.; Nogueira, A. C.; Souza, P. V. D. de. Utilização de resíduos urbanos e agroflorestais para produção de mudas de Eucalyptus benthamii e Mimosa scabrella. Floresta e Ambiente, v.20, p.530-537, 2013a. https://doi.org/10.4322/floram.2013.033

Kratz, D.; Wendling, I.; Nogueira, A. C.; Souza, P. V. D. de. Propriedades físicas e químicas de substratos renováveis. Revista Árvore, v.37, p.1103-1113, 2013b. https://doi.org/10.1590/S010067622013000600012

Lorenzi, H. Árvores brasileiras: Manual de identificação e cultivo de plantas arbóreas nativas do Brasil. 5.ed. Nova Odessa: Ed. Plantarum Ltda, 2008. 384p.

Malavolta, E.; Vitti, G. C.; Oliveira, S. A. de. Avaliação do estado nutricional de plantas: Princípios e aplicações. 2.ed. Piracicaba: Potafos, 1997. 308p.

MAPA - Ministério da Agricultura, Pecuária e Abastecimento. Instrução Normativa SDA No 17. Diário Oficial da União, Seção 1, nº 99, 24 de maio de 2007. Métodos analíticos oficiais para análise de substratos para plantas e condicionadores de solo. Brasília: MAPA, 2007. 7p.

Rocha, J. H. T.; Backes, C.; Diogo, F. A.; Pascotto, C. B.; Borelli, K. Composto de lodo de esgoto como substrato para mudas de eucalipto. Pesquisa Florestal Brasileira, v.33, p.27-35, 2013. https:// doi.org/10.4336/2013.pfb.33.73.331

Santos, F. E. V.; Kunz, S. H.; Caldeira, M. V. W.; Azevedo, C. H. S.; Rangel, O. J. P. Características químicas de substratos formulados com lodo de esgoto para produção de mudas florestais. Revista Brasileira de Engenharia Agrícola e Ambiental, v.18, p.971-979, 2014. https:// doi.org/10.1590/1807-1929/agriambi.v18n09p971-979

Silva, R. B. G. da; Simões, D.; Silva, M. R. da. Qualidade de mudas clonais de Eucalyptus urophylla x E. grandis em função do substrato. Revista Brasileira de Engenharia Agrícola e Ambiental, v.16, p.297302, 2012. https://doi.org/10.1590/S1415-43662012000300010

Trazzi, P. A.; Caldeira, M. V. W.; Reis, E. F. dos; Silva, A. G. da. Produção de mudas de Tectona grandis em substratos formulados com biossólido. Cerne, v.20, p.293-302, 2014. https://doi.org/10.1590/0 1047760.201420021134

Trigueiro, R. de M.; Guerrini, I. A. Utilização de lodo de esgoto na produção de mudas de aroeira-pimenteira. Revista Árvore, v.38, p.657-665, 2014. https://doi.org/10.1590/S0100-67622014000400009 